FROM THE TRANSACTIONS OF THE ROYAL SOCIETY OF CANADA SECOND SERIES-1903-I904

VOLUME IX SECTION IV GEOLOGICAL AND BIOLOGICAL SCIENCES

DESCRIPTIONS OF SOME NEW SPECIES AND VARIETIES OF

\title{
CANADIAN BUTTERFLIES
}

- BY JAMES FLETCHER, I,I.D., F.I.S.

\section{TOR SALE BY}

J. HOPE \& SONS, OTTAWA; THE COPP-CLARK CO., TORONTO BERNARD QUARITCH, LONDON, ENGLAND

$$
1903
$$


$8^{2}$ 

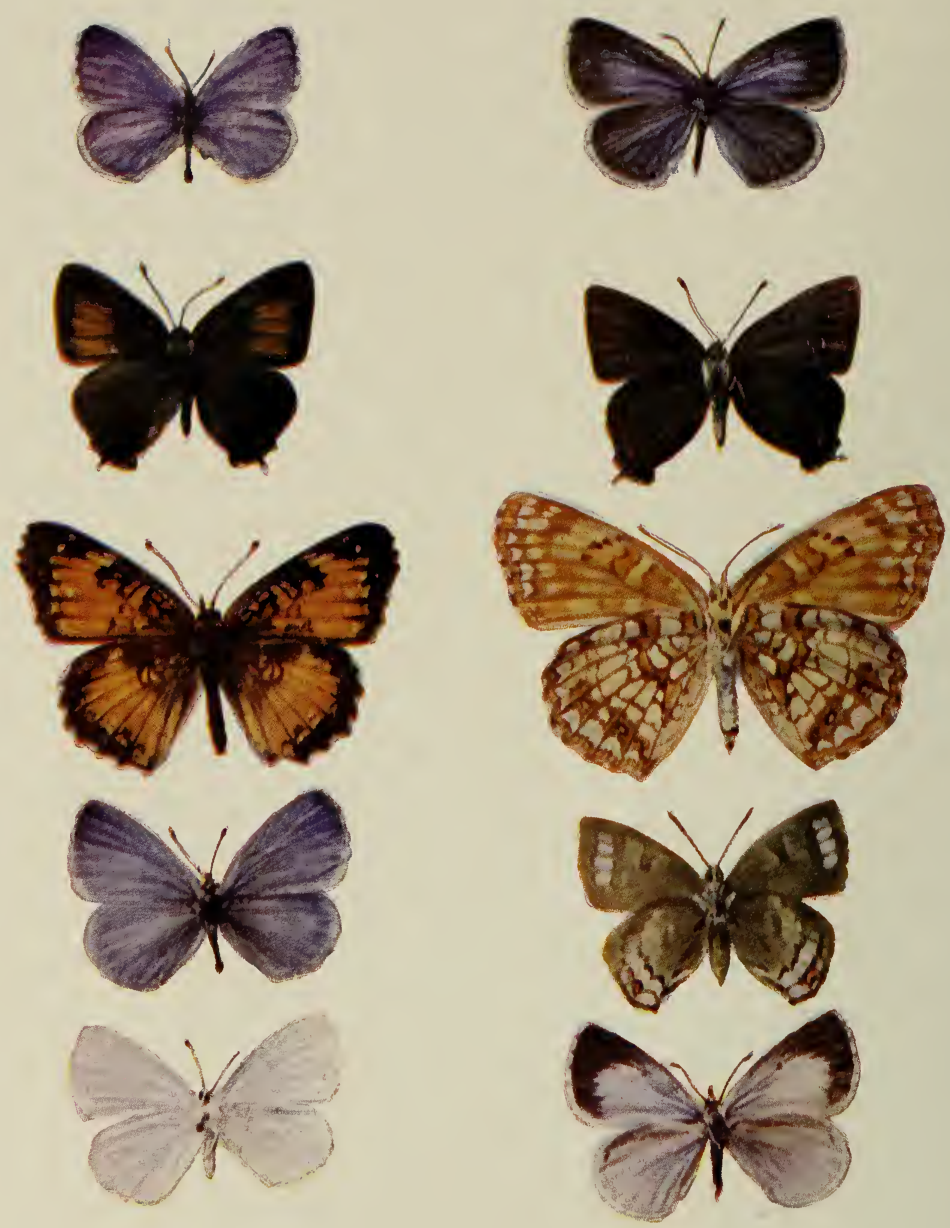

LYCAENA PSEUDARGIOLUS

VAR, NIGRESCENS $d$

THECLA STRIGOSA

VAR. LIPAROPS

PHYCIODES HANHAMI

LYCAENA PSEUDARGIOLUS

VAR. ARGENTATA $d$

VAR argentata (underside)

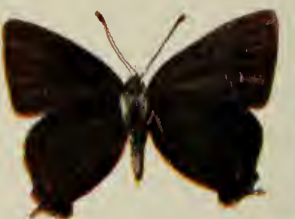




\section{XIV.-Descriptions of some New Species and Varieties of Canadian Butterflies.}

By James Fletcher, LL.D., F.L.S.

(Read May 19, 1903.)

I submit herewith descriptions of 3 species and 3 varieties of Canadian diurnal lepidoptera, specimens of which have been in my collection for many years, and of which a continued study convinces me that it is wise to characterize them for the benefit of other students of Canadian butterflies. It is possible that some of these may be only local races, but they are so constant that I believe them to be well worthy of recognition. In describing these forms, I have endeavoured to compare them with their nearest allies, as a description, even when accompanied by a plate, is far more intelligible when a new form can be compared with a well known standard. My thanks are due to Dr. Henry Skinner, of Philadelphia, who very kindly undertook the arrangement and preparation of the specimens illustrated on the plate given herewith, and also from his own cabinet provided some specimens which were better for illustration than the actual types used in the descriptions. I have also to express my gratitude to the American Museum of Natural History for a beautiful painting of Thecla heathii which was specially made for the purpose and used for the accompanying illustration, on account of two of the wings in the type specimen being imperfect. It is well here to mention that this painting is, in my opinion, almost as perfect as a drawing can be and represents exactly the appearance of the type in every mark and spot as well as in colour and shape. Mr. Wm. Beutenmuller very kindly undertook personally the supervision of this painting.

The names used in this paper are those in the recognized check lists of diurnal lepidoptera now used by American entomologists, viz.: the "List of Lepidoptera of Boreal America," by Dr. J. B. Smith, 1891, and "A Synonymic Catalogue of the North American Rhopalocera," by Dr. Henry Skinner, 1898. Up to the present time the names given by Dr. S. H. Scudder in his magnificent work "The Butterflies of the Eastern United States and Canada," have not been adopted by collectors in labelling their collections. These names, however, are, I believe, for the most part well founded, and it is merely a matter of time before they will be generally accepted. 


\section{Phyciodes hanhami, n. sp.}

\section{(Hanham's Crescent.)}

Sexes similar both in colour and markings. Alar expanse, males 37-38 mm., females 40-43.50 $\mathrm{mm}$.

Upperside. Wings bright orange fulvous darkened towards base and bordered with a clear black margin, which is widest at apex of primaries. The base and cell marked as in $P$. nycteis and with the same "tangle of black lines" mentioned by Dr. Scudder in his description of that species; the basal area, however, is never so black as in nycteis and in some specimens the ground colour is hardly darkened at all. All the veins of both wings are lined with dark brown.

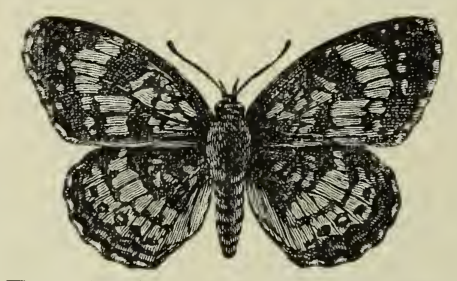

Fig. 1.-P. Nycteis, Db.-Hew.

The white marks of the under surfaces of both wings are repeated above as light yellowish contrasting spots, giving the species a much brighter appearance than nycteis, in which this feature does not occur even in the forms of that variable species where the fulvous colour predominates on the upper surface. A striking character in which Hanhami differs from both $P$. nycteis and Melitcea harrisii, a species which it also resembles, is the absence on the secondaries, above, of the median black line which in those species divides the fulvous discal area on almost all specimens. There is a more or less complete series of submarginal ocelli in the interspaces between the submarginal and median veins, but these are smaller and less distinct than in the two species named and in some specimens are obsolete. Fringes white, interrupter with black at the tips of the nervures. Underside. Fore-wings fulvous brown, marked with brown streaks and pale spots after the pattern of $M$. harrisii, but much paler and less contrasting, owing to the absence of black marks. Apical area very little darkened. There is a submarginal series of nacreous lunules in all the interspaces except the lowest, and inside this a sinuous series of pale spots. Margin fulvous, narrow, wider than in nycteis, but always narrower and more regular than in M. harrisii. Hind wings with colour areas distributed as in nycteis, but much less contrasting, the basal area being bright fulvous and the brown field at apical margin less intense in colour. At base 
are 5 large nacreous spots and a dash inside the internal vein. The triple mesial band is wide, distinct, and nacreous, the spots of the same shape and comparative length as in nycteis; but the outer transverse traversing line is somewhat angled where it crosses the nervules, that is, is made up of short, almost straight dashes as in $M$. harrisii, not of rounded crenations as in nycteis. The outer margin of this band is, as in nycteis, not clearly defined, a character in which both of these species differ from $M$. harrisii, where this is distinctly the case. Beyond the mesial band is a row of 5 ocelli, the central one of which is white, ringed with brown, and the two outer ones on each side of this are black, shaded inwardly with fulvous and pupilled with white. The most conspicuous character of this species and one by which it is easily separated from nycteis, is the complete series of large marginal silvery lunules which occur on every interspace, as in M. harrisii. In hanhami, as in nycteis, the pattern below is outlined in brown, while in harrisii the margins of the spots are black, thus producing the well-defined and distinct pattern which is characteristic of that species. Body above black, fulvous on sides, silvery beneath. Abdomen banded narrowly with white, above. Antennæ black above, banded with white, bright fulvous beneath. Palpi silvery white, fulvous at tips. I must acknowledge that I refer this species with some hesitation to the old genus Phyciodes. The general appearance and venation seem to make it congeneric with nycteis; but, at the same time, the upper sides of some specimens resemble closely extreme forms of $M$. harrisii, in which the yellow colour predominates, and in addition, the shape of most of the markings beneath is similar to those of that species. On examining a good series of specimens, the venation comes rather under the genus Charidryas, characterized by Scudder, and as figured by Holland in the Butterfly book, than under Cinclidia. Although, as stated, the markings resemble more closely those of harrisii in shape, the distribution of the colour areas is more as in nycteis. There is also in the mottled appearance of the underside a resemblance to $P$. mylitta which is congeneric with nycteis.

Distribution: Manitoba (Eastern, Central and Southern), Minnesota. The first specimens of this insect seen by me were in the collection of Mr. A. W. Hanham, at Winnipeg near which place, at Bird's Hill, he had taken them late in June, 1895. Subsequently I took several specimens at the same place and at Brandon in the beginning of July. Mr. L. E. Marmont finds the species not uncommon at Rounthwaite, Man., and Mr. Norman Criddle takes it also at Aweme, Man. Dr. Wm. Barnes writes me that he has specimens from near Minneapolis, Min. 
Described from 12 specimens (6 males and 6 females). The types of both sexes, which are figured, are deposited in the U. S. National Museum, at Washington. The species is named after Mr. A. W. Hanham, an enthusiastic and indefatigable collector, who has done so much towards working up the insect fauna of Manitoba and British Columbia.

\section{Thecla strigosa, Harr., var. liparops, n. var.}

(The Bright-eyed Hair-streak.)

In the Canadian Entomologist for November, 1895, p. 315, I referred to the Manitoban form of Thecla strigosa and expressed the opinion that this form was worthy of at least varietal recognition. This, as far as I have seen, always shows the large, rich fulvous, well defined blotches which are represented on the plate herewith. The ordinary form of T. strigosa is shown in the accompanying woodcut.

(Fig. 2.)

I have examined during the last fifteen years a great many specimens of this variety from Manitoba, and all without exception showed the two large fulvous eye-like spots on the primaries. Mr. E. F. Heath, who formerly took the insect in numbers at Cartwright, Man., writes:"I have never taken this form without the fulvous patch on the primaries in both sexes, and I have certainly taken and seen over one hundred specimens. Four or five years ago and for years prior to that it was very abundant here; now it seems to have disappeared. I do not come across one in a season."

Mr. L. E. Marmont, of Rounthwaite, Man., who has lived and collected in Manitoba for many years, writes:- "I have only 9 specimens of your variety liparops of strigosa just now; but

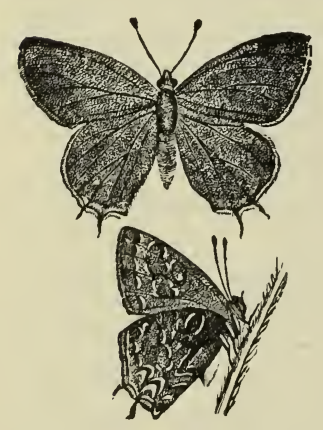

F'g. 2.-THECLA STRIGOSA, Harris, Eastern form. all have the large fulvous blotch on the fore wings. In one female it is fainter than the others, but quite noticeable; in another female the primaries are almost entirely fulvous with only a blackish border."

Occasional specimens of the eastern T. strigosa show a more or less poorly defined fulvous blotch on the upper side of primaries, but such specimens in my experience have proved to be of decidedly rare occurrence. Dr. Scudder thinks that Boisduval and Leconte intended to represent under the name of $T$. liparops $^{1}$ what we now know as T. strigosa, Harris. I can hardly think that this is the case; but it seems well to preserve the name; so, I suggest that it should be used for the variety found in Manitoba, which

${ }^{1}$ Histoire générale et iconographique des Lépidoptères, p. 99; Pl. 31, fig. 1. 
constantly shows on the primaries above a bright clearly defined blotch, and this was the chief character from which the name liparops was derived. On discussing the reference by Dr. Scudder of Harris's strigosa to Boisduval and Leconte's plate, with Mr. W. H. Edwards some years ago, the latter wrote as follows: "Scudder says this is strigosa of Harris, but no one would know it from the figures. The description is done from the figure and not from the insect; therefore, liparops represents no insect but merely the said figure, and for that reason I reject the name. The first time the insect was described was by Harris, and his name prevails." In addition to the large and handsome golden fulvous, almost quadrate patch which occupies nearly half the area of the primaries, the secondaries are also frequently ornamented with a fulvous cloud at the anal end, near the tails. The underside of the western form is of a darker brown than in the type, with the white lines much paler, these in some specimens being almost obliterated.

Described from 10 specimens taken at several places in Manitoba: Beulah (Dennis); Cartwright (Heath); Aweme (Criddle); Brandon (Fletcher); Rounthwaite (Marmont).

The types described herewith are deposited in the United States National Museum, at Washington.

\section{Thecla heathis, n. sp.}

\section{(Heath's Hair-streak.)}

Described from one female (not a male, as stated on the plate) Alar expanse, $26 \mathrm{~mm}$.

Upperside. Blackish brown (when taken), as in T. calanus. Costa at base finely edged in front with yellow as in calanus and acadica.

Underside. Fawn brown, faintly washed with white from the base almost up to a submarginal band of large pearly gray blotches which occur on all the wings. On the primaries, these are four in number and ovate. On, the secondaries, there are five square blotches and a long whitish spur running up the inner margin. Exterior to these blotches is an incomplete series of marginal lunules, as in several other allied species of the genus; consisting of, at the anal angle, between the internal and submedian veins, a few scarlet scales shaded exteriorly with as many white ones and bordered inside and outside with black; between the submedian and first median veins is a large, wide and shallow white lunule, without any scarlet scales; between the first and second median veins, a scarlet crescent outlined on both sides 
with black and shaded externally with white; between the second and third median veins is a small red lunule one-third the size of the last, shaded externally with white.

The specimen here described and figured has no tails to the secondaries, but, from the appearance of the ends of the veins and the marginal pattern, as well as the presence of a few longer scales at the end of the first median vein, I have no doubt that originally tails existed.

On the primaries the ovate blotches are bordered on each side by a broad band about two-thirds their own width, and darker than the ground colour of the wings. On the secondaries the series of square blotches is outlined on both sides by an almost black angulated line. Beyond the cell on all the wings is a large, dark, oblong quadrate blotch; the fringe on all wings is dark. Eyes ringed with pearly white; palpi white, tipped beneath with black; antennæ black, ringed with white; club orange below and at the tip.

Locality.- The type was taken by Mr. E. Firmstone Heath near his home in the picturesque valley of the Long River, a few miles from Cartwright, in Southern Manitoba. This spot is about ten miles north of the boundary of North Dakota and about twenty-five miles northeast of the Turtle Mountains. This valley, near Mr. Heath's house, is about a mile wide and is well wooded with scrub oaks (Quercus macrocarpa), ash-leaved maples (Acer Negundo), aspen and balsam poplars (Populus tremuloides and P. balsamifera), Saskatoon-berry (Amelanchier alnifolia), white thorn (Cratcogus coccinea), wolf-berry (Symphoricarpus occidentalis), prairie roses, wild plum (Prunus nigra), a few American elms, choke-cherries and various willows. Mr. Heath tells me that it was taken in July about twenty-five years ago, and, although he has been keenly on the look out ever since, he has never "seen another specimen. It is a remarkable form, and, as will be seen from the accompanying plate, which is an excellent representation, bears very little resemblance to any described species.

The species of Thecla occurring at Cartwright at the season T. heathii was taken, are T. acadica, T. calanus, T. strigosa, var. liparops, and T. titus. The pattern of the underside of the insect, here described in no way resembles that of any of these, and I can hardly think that it is a suffused albinic variety of any of them.

The type which was generously presented to me by Mr. Heath, after whom it is named, is deposited in the United States National Museum at Washington. The painting from which the figure in the plate was made, is in my own collection. 
Lycגena Pseudargiolus, Bd.-Lec., var. ARgentata, n. var.

(The Manitoba Blue.)

The beautiful variety of the common Spring Blue butterfly figurad herewith is the prevailing form in Central and Southern Manitoba, where it has usually been named by collectors var. neglecta. From this latter, however, it differs in having the black marks of the underside less distinct, in some specimens these are almost entirely obliterated so as to present a clear nearly unspotted surface of silvery white. The illustration given herewith does not quite represent the colour of the underside, rather too much of the red pigment having been used, which gives it a warm tint not seen in nature. The shade of blue of the upper surface in both sexes is, as a rule, paler than in other forms (or varieties) of pseudargiolus. In the females the discal area of primaries is silvery white with a blue reflection and a more decided flush of blue at the base.

Described from 18 specimens (12 males and 6 females) collected at Cartwright and other places in southern Manitoba, as well as in south-eastern Assiniboia. The types of both sexes are deposited in the U. S. National Museum at Washington.

Lycena PSEUdargiolus, Bd.-Lec., var. NigRescens, n. var.

\section{(The Kaslo Blue.)}

An interesting variety of $L$. pseudargiolus has been sent to me by Mr. J. W. Cockle, from Kaslo, on Kootenay Lake, British Columbia, where it is the common spring form. The most conspicuous difference between this and the other described varieties of the stem species, is the large amount of black on the upper surface of the females. This darkening forms a wide black border on the costal and outer margins of primaries, and spreads over the whole surface of the secondaries which merely show a little blue on the folds between the veins. The blue of the disc of primaries is a dark purplish blue, as in var. piasus, and is frequently irrorated with black scales. The upper side of the male is a deep rich violet blue, almost of the same shade as in amyntula. 'T'he underside of this variety is remarkable and specimens of both sexes may be found which, if the underside alone were seen, might be referred to neglecta, violacea, lucia or marginata, and some even combine characters of all of these. One beautiful form which 
frequently occurs, has an irregular discal dark blotch of confluent spots on the secondaries beneath as in lucia, and the clear marginal and submarginal spots of violacea. This form Mr. Cockle, who has collected this butterfly for several years and has been much interested in it, considers to be most typical of the variety. In all forms of this Kaslo Blue the eye-like spots of the marginal band are distinct, a character in which it differs from piasus. Some specimens, beneath, show the marginal band of marginata either with or without the confluent discal patch.

Described from 16 specimens ( 8 males and 8 females). Types of both sexes deposited in the U. S. National Museum.

\section{Pamphila manitoboides, n. $\mathrm{sp}$.}

\section{(The Nepigon Skipper.)}

In the annual report of the Entomological Society of Ontario for 1888, I described the larva of a Pamphila belonging to the comma group which Dr. Scudder and. I had taken in small numbers in the first week of July at Nepigon, Ont., north of Lake Superior. In subsequent years I have found the butterfly as early as the last week in June. In Low lands the favourite flower visited seems to be Mertensia paniculata, but on the higher rocky ridges along the Nepigon river, this skipper seems to confine itself almost entirely to the inconspicuous white flowers of Potentilla tridentata. It is extremely shy, active and difficult to catch.

This species is rather smaller than $P$. manitoba, but the markings of both sexes above are very similar to those of that species, although the colours are different. In manitoboides the upper side is a rich tawny brown with a wide very dark brown margin. None of the spats at apex of the primaries are hyaline, and the bases of both primaries and secondaries show a much less broken field of brown colour than is the case in manitoba. The male and female above are perhaps rather more like the figures of $P$. colorado, given by Dr. Scudder on plate $\mathrm{X}$, fig. 17 and 18, in his paper "On the Species of the Lepidopterous Genus Pamphila," in the Memoirs of the Boston Society of Natural History, Vol. II, Part III, Number IV (18\%4), except that the tone of colour is of a more fuscous brown and the border is darker, giving more contrast with the light shades.

Underside. A bright tawny brown in fresh specimens, primaries much darkened at the base. The whole tone of colour of the und.erside, including the dark shade at the base of primaries, and the washed cut appearance of all spots, both on primaries and the mesial band of 
secondaries, very similar to the underside of the British Columbian $P$. agricola. The mesial band is dull yellow, inconspicuous, angled and irregular, composed of the same squarish spots as in manitoba. These are perhaps normally 8 in number as in manitoba when all are present, but this is seldom the case in this species. I have only eight specimens before me at the present time: in one of these there are seven spots and a trace of the eighth; in one specimen there are seven, in five six, and in one five. The spots of the lower portion of the band, when present and of full size, confluent or nearly so, the two spots at the angle of the band usually smaller than the others. The large V-shaped spot, so conspicuous in the cell of manitoba, is inconspicuous and frequently absent. The spot at the base of the submedian interspace seldom present or very small. In the males the light colour of the spots has a tendency to run out along the veins, both towards the margin and to the base of the wings, in the same way as in $P$. uncas.

Alar expanse, males $28-31 \mathrm{~mm}$, females $30-32 \mathrm{~mm}$.

Locality: Up to the present time I have only taken this species at Nepigon, Ont., and Sudbury, Ont. Specimens sent to Mr. Henry Edwards many years ago were at first named by him Pamphila sylvanoides, but he subsequently wrote to me: "Your northern Ontario Pamphila is not sylvanoides, but must come nearer to one of the forms of comma, such as manitoba or colorado; but the underside shows that it is quite distinct from either of these."

P. manitoboides occurs at Nepigon, as stated abave, from the third week in June until the middle of July. A month or six weeks later than this the true $P$. manitoba appears, which is a rather larger insect, with a greenish tinge on the underside and distinct silvery white markings. 'The eggs of $P$. manitoboides hatch about a fortnight after they are laid, but, as has been shown by the Rev. T. W. Fyles [Canadian Entomologist XXVII (1895), p. 346], the eggs of manitoba laid in August do not hatch until the following spring. The larva of manitoboides, as described by me in the Report of the Entomological Society for 1888, does not quite agree with Dr. Fyles's description of $P$. manitoba. I have no idea that this species is very closely related to $P$. manitoba, and the name was only given to indicate a somewhat close resemblance on the upper side to that species. I did not intend, when publishing the description of the larva, that the name manitoboides should stand, and particularly mentioned in the article referred to, that, as I did not wish to cause confusion by naming what might prove to be a described species in a difficult genus which I had not specially studied, I refrained from further describing the perfect insect. Unfortunately, this precaution seems to have been unavailing, for several have written to me for further information on 
the species; and, as the name has been introduced into published lists of North American Lepidoptera, I have thought it best to prepare the description here submitted, particularly as further study has conrinced me that the species here named does not agree with any of the described species of this genus.

Described from 9 specimens (3 males and 6 females). Types of both sexes deposited in the U. S. National Museum. 

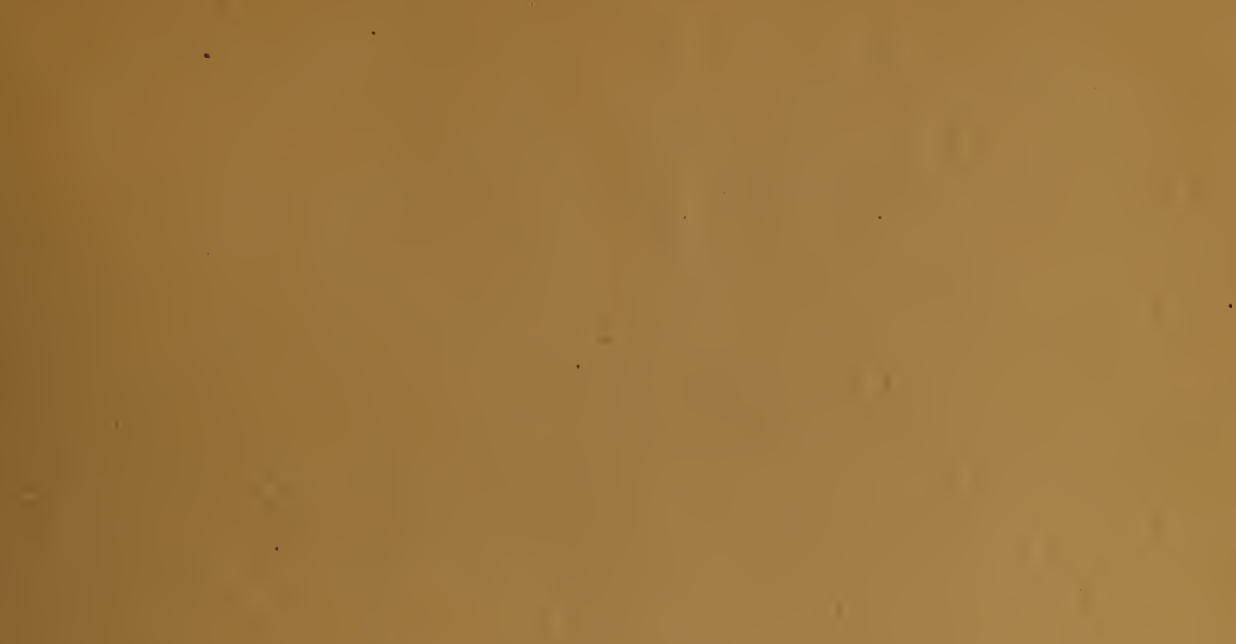

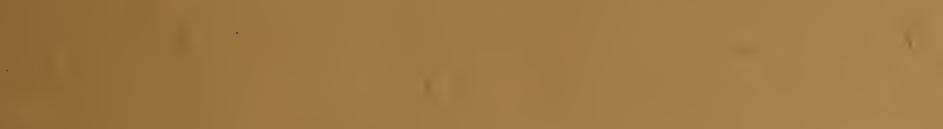

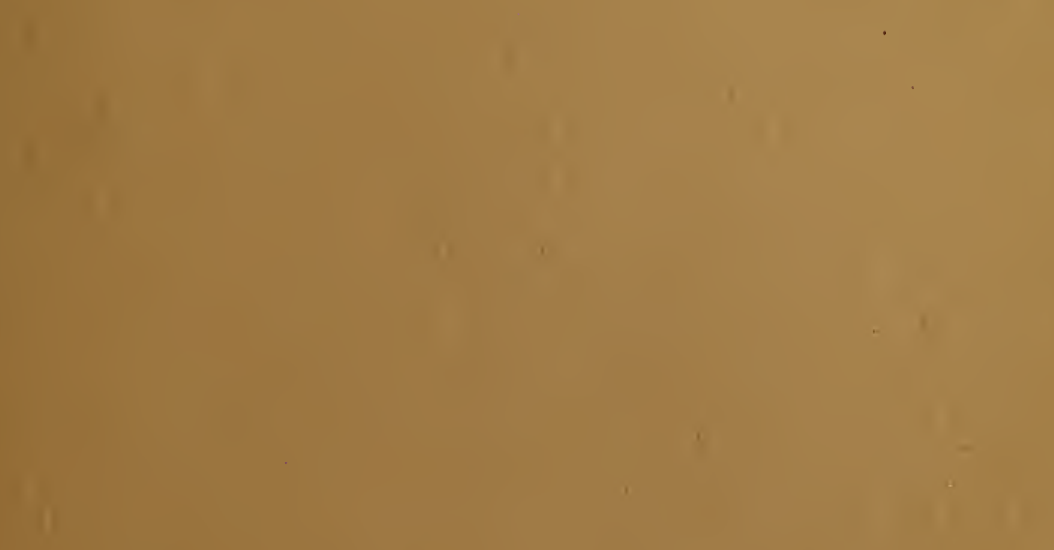


a

in

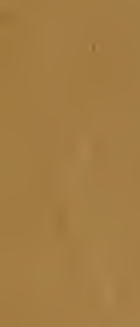

+3.

1

1

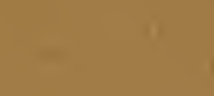

iti $4=$

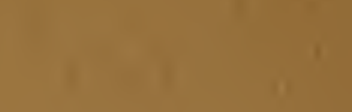

$x-11$
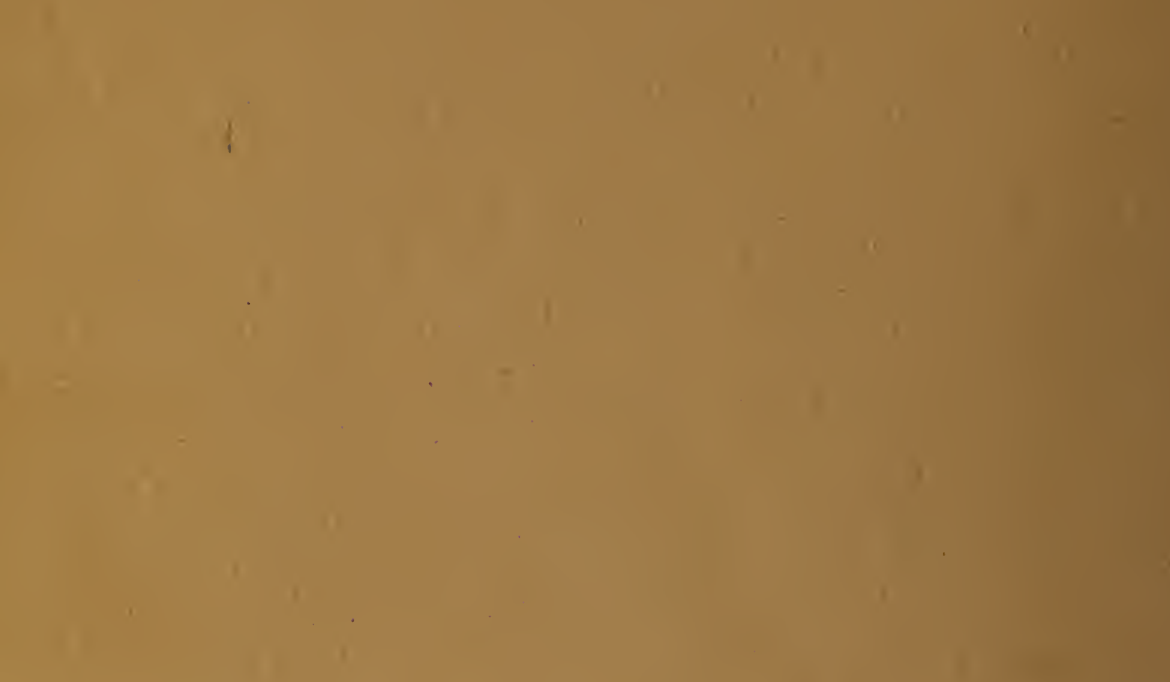

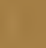

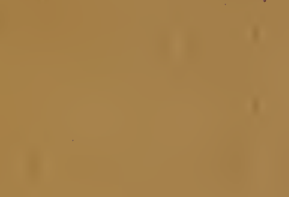

(1)

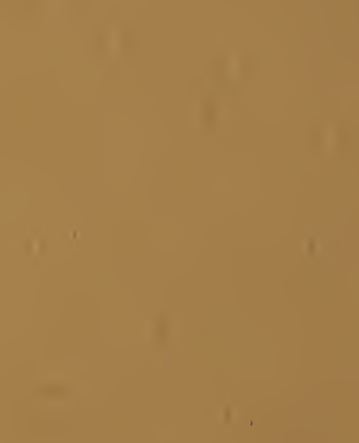

in.

$=11$

17

v

it)

i1.

1 it

1. 